\title{
Lessons from Ciência Viva: how teaching human genetics to XXIst century students must go beyond the classroom
}

\author{
Meghan Quint ${ }^{1} \cdot$ Olga Amaral $\mathbb{D}^{2}$
}

Received: 12 August 2019 / Accepted: 29 October 2019 / Published online: 18 November 2019

(c) European Society of Human Genetics 2019

Science and technology education plays a vital role for decision making in an informed society as well as for informed choices in a pre-university setting. In 1997, Portugal launched a national Science program known as Ciência Viva Summer Internship Program (SIP) which, along with other initiatives such as the Science Centers and science annual events, aiming to bring science awareness closer to the population. The free SIP provides short term internships to Portuguese secondary school students throughout the country. We advocate for public and private research institutions across Europe to maintain involvement in, or create, similar scientific development opportunities that are free of cost to students. We recognize that initiatives like these require the proper infrastructure and interest amongst researchers. However, we stress the long-term benefit to the scientific community as well executed programs help draw interest towards Science fields.

According to the Ciência Viva website, in the first iteration of SIP in 1997, 11 institutions throughout Portugal hosted 130 students. In the most recent iteration evaluation of SIP (2018), over 300 institutions hosted over 800 students. University laboratories, public and private research institutions, all participate in SIP. As shown in Fig. 1, to date, over 16,500 students have participated in Ciência Viva SIP [1]. In 2004 there is a noticeable decrease in student participation which is possibly correlated with less researchers and placements as well as slight investment decrease in Research \& Development [2].

Olga Amaral

olga.amaral@insa.min-saude.pt

1 Hobart and William Smith Colleges (HWS), 300 Pulteney St., Geneva, NY 14456, USA

2 Instituto Nacional de Saúde Dr Ricardo Jorge (INSA, IP), Departamento de Genética Humana, Unidade de Investigação e Desenvolvimento, Rua Alexandre Herculano 321, 4000-055 Porto, Portugal
In the summer of 2019, two enthusiastic students entering their final year of secondary education at different public schools in the greater Porto area interned for 1 week in the Department of Human Genetics at Instituto Nacional de Saúde Dr Ricardo Jorge in Porto, Portugal. After brief theoretical introductions, they demonstrated a strong understanding of the scientific topics and an enormous learning capability. They were thrilled to integrate into a real team of scientists while carrying out their tasks and observing lab members perform more complex work. With guidance, the students extracted DNA from a fibroblast cell line and conducted two PCRs experiments: one to determine if there was a polymorphism in a gene that acts as a common biomarker in some rare Genetic Diseases and another to determine the gender of the cells [3, 4]. At the end of the internship the students gave a short presentation on ethics, based on the subjects that they had been learning about, focusing mostly on iPSCs and genome editing.

At the same time, INSA had an undergraduate student from the United States interning in the laboratory. This provided the two girls with a unique experience as they were able to practice their English, learn a different perspective on research, and ask questions about education and life in another country. These small, unique opportunities that arise from free, structured programs like Ciência Viva allow young students to feel welcome in the international scientific community and make informed decisions about their future.

The students noted that despite learning basic cell biology and molecular genetic techniques in school, this was their first time interacting with practical work in a long-term project which ultimately provided a better understanding of their coursework. By the end of the internship, the two students noted that they appreciated the time researchers took to integrate them into meaningful work. One stated that in school she often feels like the experiments they complete have no larger purpose, but SIP allowed her to practice her laboratory techniques while feeling like she was a part of something bigger. This is in agreement with prior mass studies on SIP participants. Furthermore, in those studies, more 


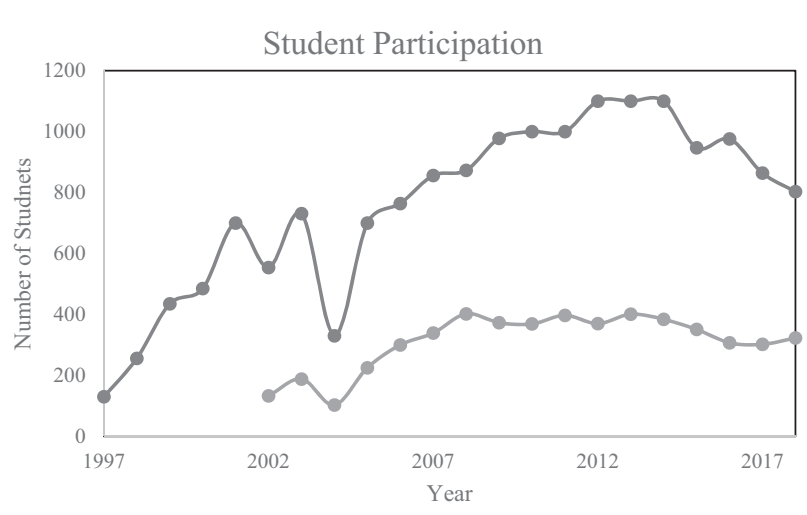

Fig. 1 In blue is the number of students from 1997 to 2018 who participated in Ciência Viva SIP. In orange is the number of placements for students from 2002 to 2018. Based on data available, adapted [1]

than half of the respondents considered the internship to be excellent and students tended to most enjoy the opportunity to engage in practical work [5, 6]. The students continued to feel enthusiastic about genetics as they worked with concepts hands-on in a laboratory setting. Ultimately, this experience and excitement will be shared with their peers.

Secondary school curriculum in biology often presents oversimplified molecular genetics which prevents highly capable students from understanding the fascinating complexities that are currently being explored in the field [7]. This oversimplification underestimates the capability of the students who may lose interest in a potential, future career in genetics. For the genetic related skill development in highly motivated students it is essential to have direct interaction with scientific materials beyond the classroom which can only be facilitated by experiential programs. By exposing students to innovative research, via programs like SIP, they are able to effectively apply their knowledge of the basics to more complex research questions and demonstrate their outstanding troubleshooting capabilities that have been fostered by an age of technological advancement.

Genetics education should not be limited to the classroom as it leads to gaps in the education of high achieving students. Finally, experiential education engages the student with scientific investigation and new technological developments at a deeper level while benefiting the researcher, as they must respond to new demanding questions posed by students from a new scientific paradigm. Education is a "joint participation of teacher and student in the effort toward understanding" which SIP achieves via the personal involvement and collaboration of researchers and students rendering the experience beneficial and enjoyable for all [8].

Acknowledgements The authors thank the Department of Human Genetics, the UID group of Porto and the participating students for the positive interaction.

Funding MQ received financial support for an internship at INSA from Bickley Summer International Internship Stipend via the Salisbury Center for Career, Professional and Experiential Education at Hobart and William Smith Colleges; OA received funding from FCT grant PTDC/BIM-MEC/4762/2014.

\section{Compliance with ethical standards}

Conflict of interest The authors declare that they have no conflict of interest.

Publisher's note Springer Nature remains neutral with regard to jurisdictional claims in published maps and institutional affiliations.

\section{References}

1. Ciencia Viva EDIÇÕES ANTERIORES: Ciencia Viva. https://www. cienciaviva.pt/ocjf/2019/edicoesanteriores.asp?accao=changelang\&la $\mathrm{ng}=\mathrm{en}$.

2. Projectos de I\&D FTC- Fundação para a Ciência e a Tecnologia. https://www.fct.pt/apoios/projectos/estatisticas/\#vi.

3. Weiss AS, Johnston JM. Sex determination using the polymerase chain reaction. Biochem Educ 1999;27:237-9.

4. Boot RG, Renkema GH, Verhoek M, Strijland A, Bliek J, de Meulemeester TM, et al. The human chitotriosidase gene. Nat Inherit Enzym Defic J Biol Chem. 1998;273:25680-5.

5. Alves CHC. Learning science through work experience: a Ciência viva science internships programme for senior secondary students. $\mathrm{PhD}$ Thesis at Cambridge University, UK: University of Cambridge; 2007.

6. Alves CC. Learning science through work experience: ciencia viva internships program for secondary school students. Int J Sci Soc. 2012;3:13-26.

7. Dougherty MJ. Closing the Gap: Inverting the Genetics Curriculum to Ensure an Informed Public. Am J Hum Genet. 2009;85:6-12.

8. Hirschhorn K. Education: A Joint Effort*. Am J Hum Genet. 2003;72:242-3. 